\title{
'In the interests of our people': the influence of Garveyism on the rise of Australian Aboriginal political activism
}

\author{
John Maynard
}

\begin{abstract}
'It is difficult to predict when new pasts will erupt through the surface of established understandings and change the landscape of the future'. ${ }^{1}$
\end{abstract}

In August 1924 a letter sent from an Aboriginal man, Tom Lacey, in Sydney to Amy Jacques Garvey - associate editor of The Negro World - reveals new insights on the rise of early Aboriginal political activism. Amy Jacques Garvey was the wife of Marcus Garvey, at the time probably simultaneously the most revered and despised black man on the planet. Garvey was the leader of the Universal Negro Improvement Association (UNIA) which remains the biggest black movement ever established in the United States. ${ }^{2}$ The letter from Lacey was published in Garvey's Negro World under the banner 'Australia sends Greeting to the Fourth International conference'. ${ }^{3}$ This article explores the significance and genesis of these international black connections with early Aboriginal political leaders on the Sydney waterfront.

The large-scale revocation of independent Aboriginal reserve lands in NSW between 1910 and 1925 and the brutality of taking Aboriginal children from their families $^{4}$ were the galvanising issues that ignited Aboriginal political revolt and led to the rise of the first united organised Aboriginal political group, the Australian Aboriginal Progressive Association (AAPA). ${ }^{5}$ The Aboriginal reserve land was turned over to white farmers, returned soldiers (World War I veterans) and urban expansion. ${ }^{6}$ The Aboriginal occupants, after decades of blood, sweat and tears, were turned onto the street with little more than the shirts on their backs. It was against this backdrop of oppression that the AAPA arose to inspire their people.

1. Davis 2001: 95 .

2. Dawson 2001: 2; Levine 1993: 122; Martin 1983: 100.

3. The Negro World, 2 August 1924.

4. 'The Stolen Generations' - a State government policy of forced removal of Aboriginal children from their families. See Commonwealth Government, Human Rights Equal Opportunity Commission 1997; Read 1999; Haebich 2000.

5. Goodall 1996: 151

6. Goodall 1996: 151 


\section{Black maritime workers: the seeds of political mobilisation}

During the opening decades of the twentieth century at the Sydney docks, contact between Aboriginal men employed as wharf labourers and international black seamen led to communication and inspiration. Through this contact, an appreciation of an international black struggle developed among Aboriginal people. They realised they were not alone, and that others around the globe were now speaking out against oppression, racism, and prejudice directed against black people.

The first indication of serious international black influence upon later Aboriginal political mobilisation is the formation in Sydney around 1903 of an organisation called the 'Coloured Progressive Association'. (The name itself may have had some bearing some 21 years later on the naming of the 'Australian Aboriginal Progressive Association'.) The CPA and its links to Aboriginal people were undoubtedly a result of working connections on the Sydney waterfront, at the time a major and busy international port. The Coloured Progressive Association's membership largely comprised African Americans and West Indians although there is evidence that Aboriginal people were also involved. ${ }^{7}$ The great majority of the international black men could not have been Australian nationals, but would have been foreign transitional seamen. As race theory took hold in the mid-nineteenth century, the multiracial and revolutionary unity which had previously existed between mariners of all ethnic backgrounds disintegrated. ${ }^{8}$ The early decades of the twentieth century were a period in Australia with high levels of overt racism. The implementation of the 'White Australia' policy with its significant long-term ramifications was a famous product of the era. 'Australia first put a tax on coloured people, increased the tax, afterwards limited the number, and finally prohibited their entry' ${ }^{10}$ International black commentators were scathing:

There is Australia, a great empty continent containing five million people where it could easily support one hundred million. It is being held for white settlers who do not come, while coloured people are being kept out. Let Australia open its doors to its natural coloured settlers. ${ }^{11}$

Conditions for international black seamen were harsh in Australian ports at the time. One Jamaican seaman displayed his disgust by refusing to turn out for the customs inspection. He was forced to appear in court and replied to the magistrate:

'We went to Newcastle, had to pass customs; went to Wallaroo, had to pass customs; came to Port Adelaide had to pass customs. Once I was undressed, and they made me come up. There are 12 of us coloured men on the ship, and we want to know why we should be singled out. The ship is chartered, and we came to work the ship, not to live here. We do not see why we should have to pass the customs every time we come into port.'

\footnotetext{
Maynard 2003a: 95.

Linebaugh \& Rediker 2000.

'White Australia'. All government parties campaigned on a White Australia policy at the first general elections in 1901 and the new restrictive legislation was among the first enacted by the national parliament. It was not until 1967 that a more positive practice of allowing a flow of coloured immigrants into Australia was adopted (Murphy 1982: 282).

10. Daylight, 29 November 1924: 809.

11. The Crisis 23(3) January 1922.
} 
Defendant was ordered to forfeit two days' pay, and to pay $£ 21 /$ - costs. As he left the court he bowed to the magistrate and said, 'Good Morning Sir'. ${ }^{12}$

In 1904 a deck crew of 20 'Lascars' had left a ship docked in Melbourne and camped on shore, refusing point blank to return to the vessel. They complained to authorities of ill-treatment while working on an Australian-owned vessel Argus, and said that they had been assaulted by the captain:

Under the Aliens Act the captain of the Argus is liable to a penalty of $£ 100$ a man should any of them remain ashore.

The 20 Lascar deck hands who struck work on the steamer Argus at Williamstown yesterday, walked to Melbourne during the night and this morning they interviewed the shipping master. They explained that their wages ranged from 10 to 35 rupees per month, but that none of it could be handled until they returned to the port from which they shipped.

Captain Currie, of Currie and Co., owners of the Argus, and captain Sutherland, master of the steamer, were present at the interview.

Eight of the men complained that they had been struck by the captain. They all declined to go on board unless there was a fresh captain. They would sooner go to gaol. After some angry passages, captain Currie said he would take out warrants and have the men imprisoned till the time of sailing. When they got back to Rangoon they would be discharged. The charges against the captain were denied by the captain and the first mate. ${ }^{13}$

The following day the men appeared before the city court and received no support to their pleas of abuse. The captain was exonerated, and the crewmen, brave enough to stand up in the face of abuse, were penalised:

The 21[sic] Lascar seamen who went on strike from the steamer Argus on Sunday, owing as they alleged to ill-treatment by the captain were before the city court today. Captain Sutherland said he had not touched any of the men, and he had heard no complaints.

The Bench, after hearing further evidence ordered 18 of the men back to the steamer, whilst the others, who were said to have caused the trouble were remanded for a week. ${ }^{14}$

Twenty years later, conditions for international black seamen remained harsh in Australian ports. A crew of West African seamen went on strike whilst their ship was in dock at Newcastle. It was noted in the press that the captain of the vessel would 'have to support them on board or pay a penalty of $£ 100$ a man if they remain off the ship more than 24 hours' ${ }^{15}$ Although some white groups opposed the restrictive policies that targeted black visitors, ${ }^{16}$ similar severe experiences for black seamen existed in other ports around the globe during the early decades of the twentieth century. Many

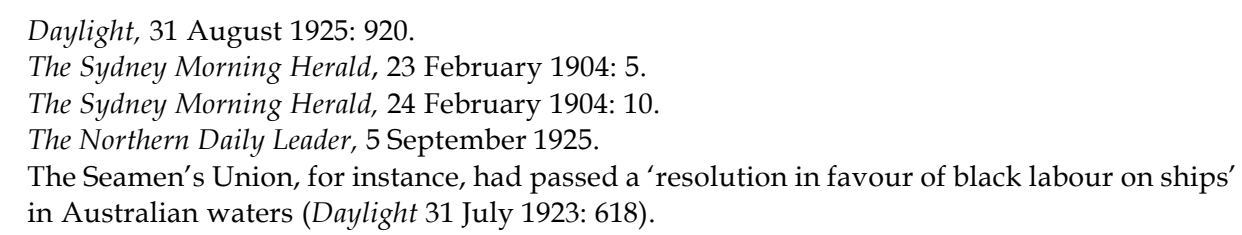


black seamen were forced to live in extreme poverty in English ports like London, Liverpool, Cardiff and Hull:

Dumped from tramp steamers or attracted by the prospect of casual work ... black seamen found it hard to get another ship, harder still to find work ashore. Most white seamen rejected them as shipmates; white dockers, too refused to work alongside them. Having spent the small sums they had been paid off with, having pawned any spare clothes and other belongings, destitute seamen tramped from port to port, desperate for work. Their quest was endless and almost hopeless. Help from compatriots and parish hand-outs kept them from starving. ${ }^{17}$

The formation of the Coloured Progressive Association in Sydney was undoubtedly a result of similar experiences. Black men and women with maritime connections congregated together for support in the face of mutual hardship and isolation.

\section{Jack Johnson and the Coloured Progressive Association}

The Coloured Progressive Association itself may never have been noticed by the media - and might simply have faded into oblivion - except for the arrival in Australia in 1907 of one extremely high profile individual. Heavyweight boxer Jack Johnson was one of the most charismatic and talented sporting identities the world has known (fig 1). Certainly the coming of Johnson to Australia gave Aboriginal people an identifiable black icon of great celebrity to cheer, and something to aspire to. Johnson had for years been denied the opportunity of fighting for the Heavyweight Championship of the World. He had two fights during his first Australian visit, knocking out both West Indian Peter Felix and Australian Bill Lang.

An advertisement in the Referee on Wednesday 13 March 1907 drew attention to Johnson's imminent return to the United States and that an organising body called the Coloured Progressive Association of New South Wales, described as a 'solid influential Sydney body', was holding a farewell function in his honour. ${ }^{18}$ Some of the organisation's office bearers were named: 'Mr. W. Grant is grand president, Mr. H. Gilbert treasurer, and Mr. G. Phillips secretary' ${ }^{19}$

The program arranged is a capital one for such an occasion. Some of the leading Tivoli and National Amphitheatre artists, including Miss Casey Walmer, Chas Pope, Harry Ingram and others will assist. Jack himself is billed for a display of ball punching, which should prove a treat in itself. First class music is promised, and dancing and singing will run from 8 till $12 .^{20}$

The farewell to Johnson, at Leigh House in Sydney, evidently well-attended and an undoubted success, was given sarcastic racist coverage by the Truth:

The gorgeous mirrors of the dance-room reflected the gyrations of the coloured cult of the city ... white men (a very few) ambled around with full black, half and quarter caste beauties ... Three white ladies toed the 'shazzy' in amazing shoulder cut evening dresses. One of these charmers had on a blazing red costume, and she made a paralysing start in a waltz. ${ }^{21}$

\footnotetext{
Fryer 1984: 294-295.

18. The Referee, 13 March 1907.

19. The Referee, 13 March 1907.

20. The Referee, 13 March 1907.
} 


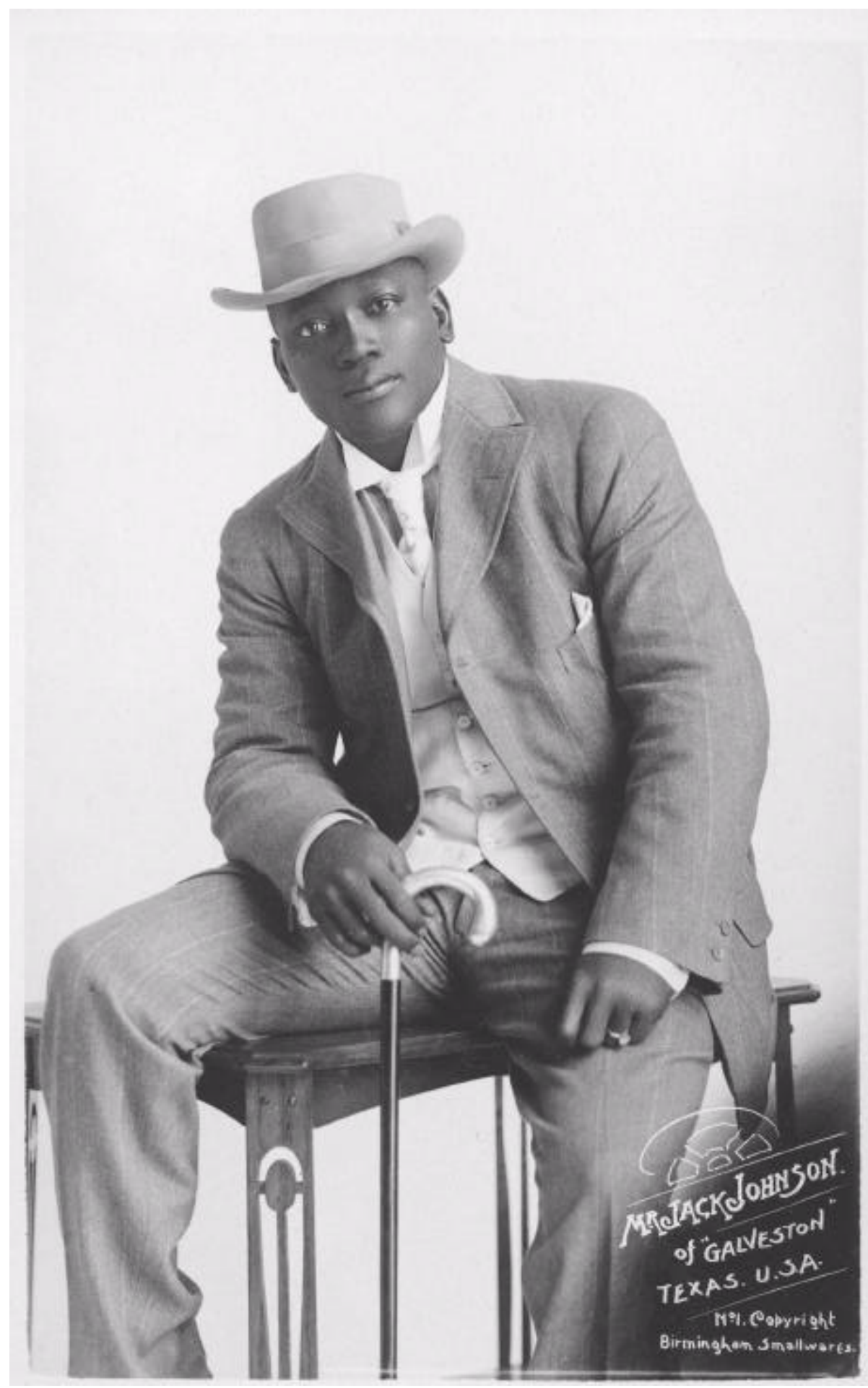

Fig 1 Dapper Jack Johnson wearing his beige tweed suit, 1908. NAA A1861, 848 'Boxer Jack Johnson of Galveston, Texas'. 
Jack Johnson was depicted as looking magnificent when he arrived in a light square-cut tweed suit. He moved at ease amongst the crowd throughout the evening but did not take to the dance floor himself. Later in the night Johnson left in a hansom cab. He returned shortly after 11 o'clock. 'Coyly clinging to his ebon wing was Cassie Walmer of the Tiv. The pair accompanied by a select small party did a duck upstairs' ${ }^{22}$ Highlights of the dancing during the night present further evidence of the maritime background of those present: 'a quadrille was in progress shortly after 11 o'clock, and some sable dancers were displaying bell bottomed trousers with great effect' ${ }^{23}$

Despite its glaringly offensive tone, the article presents historical evidence of the Coloured Progressive Association at the time. The president, an elderly 'coloured' gentleman and a former steamtug captain, W Grant, indicated to the reporter that the organisation had a membership of ' 40 or 50 and had been in existence about four years'. 24

He also let it be distinctly understood that the Black Progressives didn't like the Commonwealth restrictive legislation. They want an open black door, which coons can enter at their own sweet will. ${ }^{25}$

The journalist completely dismissed the thought that Aboriginal people could have been a part of the evening. Educated and elegantly attired Aboriginal men and women were out of the realm of his imagination.

Comfortably disposed about the lounges were ladies white and coloured. Some of the latter were full-blown negresses, and there was a mixture of half-castes, quadroons and octoroons. On each side of the ballroom were seated black wallflowers, interspersed with a few whites. The coloured gentlemen and ladies were almost entirely of the American type. The Coloured Progress Association does not evidently include the La Perouse shade. ${ }^{26}$

But a photograph of the event (which clearly identifies Jack Johnson and West Indian boxer Peter Felix) shows that the future AAPA President Fred Maynard was also present at Johnson's farewell in Sydney (see fig 2).

No further mention or account of the Coloured Progressive Association has to date been found. Hopefully further research may uncover what became of this organization, its membership and explore further links to the later Aboriginal political movement. Jack Johnson had displayed interest, knowledge and appreciation of traditional Aboriginal life during his visit. 'I spend most of my spare time in the art galleries and the museum', he stated.

My principle hobby is archaeology. When I visit your museum and see the numerous specimens of prehistoric man's art, your boomerangs of many varieties, your stone axes from various States and the many examples of Paleolithic and Neolithic man's skill - simply I envy you. America had its rude implements but they did

\footnotetext{
21. The Truth, 17 March 1907.

22. The Truth, 17 March 1907.

23. The Truth, 17 March 1907.

24. The Truth, 17 March 1907.

25. The Truth, 17 March 1907.

26. The Truth, 17 March 1907.
} 


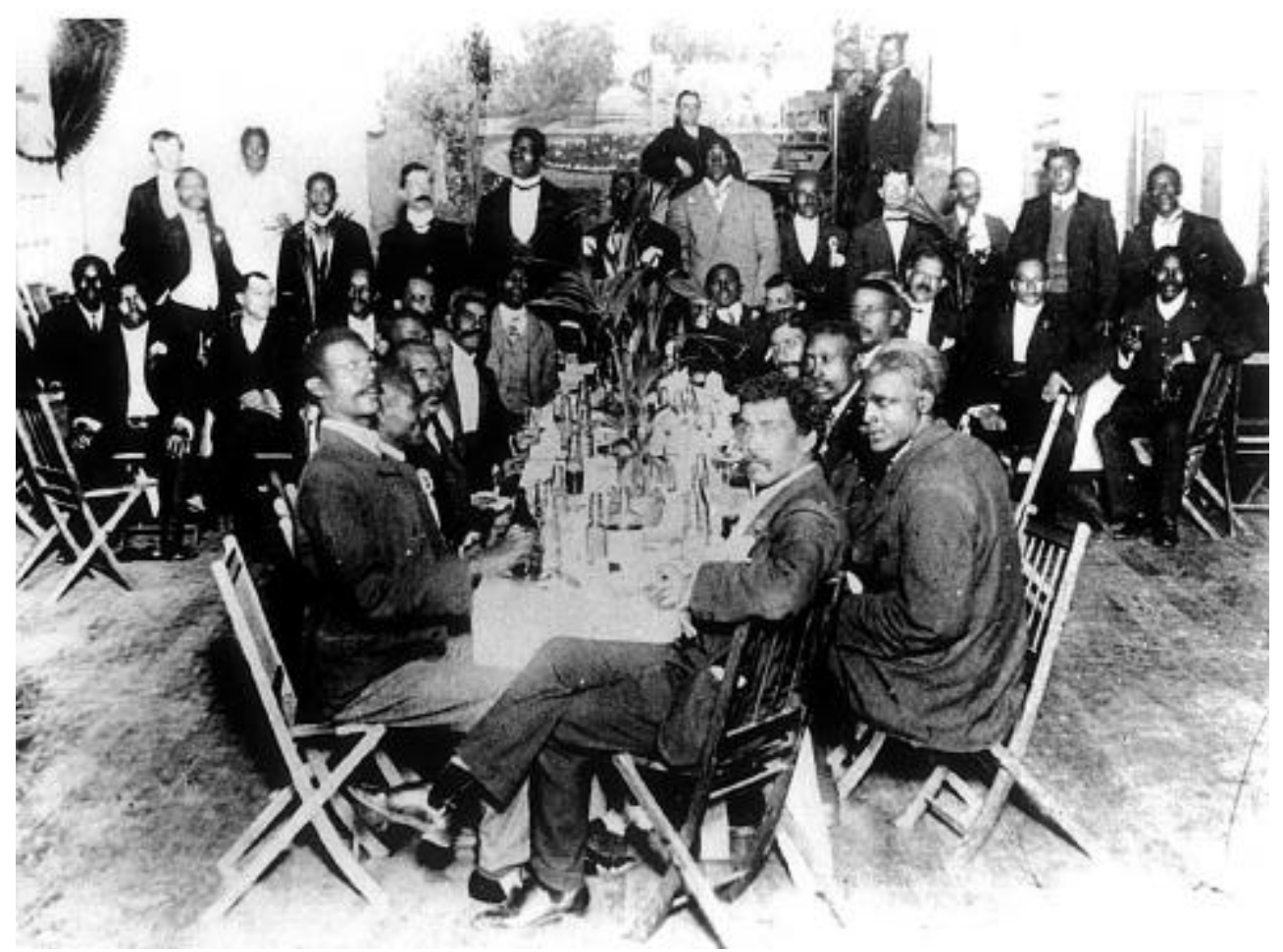

Fig 2 Coloured Progressive Association farewell to Jack Johnson Sydney 1907. Johnson is standing at the back in the pale suit, to his right the other tall man is West Indian boxer Peter Felix. My grandfather, Fred Maynard, is the third from the right and to Johnson's left. Maynard family photograph, courtesy Cheryl Oakenfall.

not show anything like the same foresight. The Australian natives must have been geniuses to invent such weapons. ${ }^{27}$

Late in 1908 Johnson returned to Australia to fight for and win the Heavyweight Championship of the World. It is worth noting that Johnson was given the privilege of official exemption to enter the country to take part in the fight. ${ }^{28}$ He met the Canadian world champion Tommy Burns in Sydney. Burns was offered the incredible sum of $£ 6,000$ to defend his title against Johnson in Sydney. Johnson was to receive $£ 1,000$ for the fight; under the circumstances of being denied the opportunity for so long he would probably have climbed into the ring for nothing. ${ }^{29}$

The fight attracted international media interest in an Australian-held sporting event that would be unparalleled until the staging of the 1956 Olympic Games in Melbourne. The fight was held at the specially constructed open-air Sydney Stadium. It was a sell-out. Twenty thousand people jammed into the stadium, with a further 40,000

27. Wells 1998: 178

28. 'Relative to the issue of Certificate of Exemption in favour of Jack Johnson', NAA Memo No $5934 / 08$, D596.

29. Corris 1980: 93. 
locked outside. Johnson completely destroyed Burns in the ring. All the years of racial prejudice, persecution and denied opportunity spurred him on. During the fight Johnson continually taunted Burns, telling him he punched like a woman, and that Mrs Burns would not recognise him when he got home. 'At one point, Johnson exposed his right side and told Burns to hit him with all his might. The champion complied and Johnson didn't even wince'. ${ }^{30}$ Burns was knocked down three times in the first two rounds and the pattern of the fight had been established. However, Johnson had no intention of ending it early. He was like a cat playing with a mouse. The beating Burns took was so complete that the police eventually jumped into the ring and stopped the punishment.

The news of this great - black - victory spread around the globe and rapidly through Aboriginal and Pacific Island communities where it was received with 'great delight' ${ }^{31}$ A Solomon Islander who was present at the Burns-Johnson fight as a young boy later described it as 'the greatest day of my life'. ${ }^{32}$ Years later Johnson himself recounted that during the break between rounds, his eyes surveyed the crowd, and he drew strength from a black man whom he saw in the audience:

As my gaze wandered out into the surrounding territory, I saw a colored man sitting on a fence watching the fight with open mouth and bulging eyes. My glance returned to him again and again. He was one of the very few colored people present, and he became a sort of landmark for me. ${ }^{33}$

Fears of the consequences of such identification of black Australians with Johnson's victory underlay attempts to suppress the news of Johnson's win in such places as the Solomon Islands, "where it was felt the "natives" might take an inappropriate message from it' ${ }^{34} \mathrm{~A}$ writer in the Bulletin screamed, 'Johnson's behavior in the ring was objectionable, so much so that if it had happened in America, someone would have shot him dead to the cheers of the crowd and given the film as defense evidence and got a verdict of "justifiable homicide"'. ${ }^{35}$ Randolph Bedford, writing for the Melbourne Herald, did not hold back his scorn for Johnson. 'Already the insolent black's victory causes skin troubles in Woolloomooloo,' he moaned. 'An hour after, I heard a lascar laying down the law of Queensberry to two whites, and they listened humbly. It is a bad day for Australia'. ${ }^{36}$ Bedford's article incited a race debate that raged on the letters page of the Melbourne Herald. One writer, signed as 'Uncle Tom', commented dryly:

Reverse the conditions, which prevailed at Sydney and place a white boxer in a ring in a southern State in America, with a huge crowd of hostile blacks, it would be pardonable if he replied to their taunts as Johnson did on Saturday. If Jack Johnson's critics are not satisfied with him I might remind them that there are millions of highly cultured colored gentlemen in America and other parts of the world who possess as high an order of intelligence, and certainly more humanity than Mr. Randolph Bedford. ${ }^{37}$

\footnotetext{
Fleischer nd: 18

Corris 1980: 94 .

2. Corris 1980: 94.

Wells 1998: 245.

Corris 1980: 94.

Corris 1980: 94.

36. Wells 1998: 197.
} 
Johnson returned to the United States where he knocked out Stanley Ketchel, and then the 'Great White Hope', Jim Jeffries. After the Johnson-Jeffries fight, race riots erupted in the United States. Whites reacted angrily when Jack Johnson seemed to first toy with Jeffries and then knocked him out in the fifteenth round. The violence of the race riots made world headlines. ${ }^{38}$ Both the black and white population had looked forward to the match against the much vaunted Jeffries:

Johnson's notoriety while in Australia and the high degree of racial hostility associated with his fights here and in the USA meant that many people were eagerly following the fight in $1910 .{ }^{39}$

A squatter on the north coast of NSW, Cunningham Henderson, later recorded his memories of the Johnson-Jeffries fight. Henderson's recollections offer a valuable insight of the differing black and white sentiments surrounding this major sporting event. Henderson recalled that he was helping his friend, Tom Yabsley, to muster cattle:

It was the day of the Johnson-Jeffries fight in America. Because of Johnson's colour the black boys took a keen interest in the fight and were discussing it. Just then a blasting shot went off in a stone quarry a few miles away, which we heard plainly. Yabsley turned quickly to Alfie and said - 'Did you hear that?' 'Yes Boss What that feller?' 'That was Jeffries hitting Johnson!' Alfie quickly cupped his hand, held it to his ear, and striking a listening attitude, said - 'No Boss, I never heard the people shout!' (meaning there was no applause) The laugh was against the boss. 40

The recall of this incident by Henderson and the sarcastic 'banter between the whites and blacks about it, all suggest that its significance ran deeply for them all' ${ }^{41}$

The significance and impact that Jack Johnson made on the international black population around the globe cannot be underestimated, as boxing writer Jeff Wells revealed:

The fists of Jack Johnson had rattled the white world - even from the farthest outposts of the British Empire came angry reports about bumptious natives. White America now trembled for its women. White manhood had shrivelled. While a black mistress - especially in the south - was considered a passable fashion accessory for a white man it was unthinkable that white women might begin submitting to the charms of black men. Johnson had long flaunted his affairs with white women at a time when a black man could be lynched for even the slightest sexual suggestion to one. In fact, during Johnson's reign as champion 354 black men were lynched -89 for alleged offences against white women. ${ }^{42}$

Marcus Garvey, who himself would figure prominently as a rallying and inspirational figure for Aboriginal Australians, once declared 'a strong man is strong

37. Wells 1998: 197.

38. See, for example, 'Race Riots in America, 19 deaths, many hurt and 5,000 arrested' The Daily Express (London), 6 July 1910 (headline).

39. Recollections of Mr C. A. Henderson, 1864-1950, Mitchell Library MSS 1863, 7-734, quoted in Goodall 1998: 70-71.

40. Recollections of Mr C. A. Henderson quoted in Goodall 1998: 70-71.

41. Recollections of Mr C. A. Henderson quoted in Goodall 1998: 70-71.

42. Wells 1998: 228-9. 
everywhere $^{\prime 33}$ and Jack Johnson was such a man. He was, Garvey said, 'strong everywhere he went. He had beaten his white opponent in Australia, he had beaten them in the United States and he could beat them wherever they presented themselves. He was strong, and it did not matter where you took him, he was still strong'. ${ }^{4}$

\section{The aftermath of World War I: the rise of black political consciousness}

There is little doubt that Aboriginal wharf labourers continued their association with international black seamen prior to, during and after World War I. During the 19031935 period, 335 African, African American and West Indian people entered and left Australian ports. ${ }^{45}$ In a six-year period from 1912 to 1917, 106 of these international black visitors entered and left Sydney. ${ }^{46}$ The acceleration of contact between Aboriginal wharf laborers in Sydney and visiting black seamen during this period of world turmoil could well have set the foundation for the launch of Aboriginal political agitation in 1924.

The end of World War I was a catalyst for great change. The Western imperial powers had been weakened and their position of expansionist superiority seriously eroded. The 'inevitability of peaceful progress under the auspices of liberal capitalism $^{\prime 47}$ had been severely shaken. The war 'altered the course of world history in ways that strongly affected black protestors in the United States and Africa' ${ }^{48}$ One black speaker at a New York UNIA meeting in 1922 passionately declared:

You are asked to go and fight the Germans who had done you no wrong. You were told to give the Germans hell, while they were giving you hell over here, and while you were giving the Germans hell, they were giving your mothers, sisters and sons hell in Mississippi, Georgia, Alabama and then the Negro asked 'which is better, to make the world safe for democracy, or to make his home safe for his wife and children'. That is what he asked then and what he is asking now. ${ }^{49}$

Around the world many oppressed groups including Indigenous peoples gained in confidence and found a political voice. Many of these groups were inspired and fuelled by a surge of national and cultural pride, and their political agenda was driven under "the banner of "self-determination". 50

This upsurge in international protest and demand was reflected in Australia with the rise of the Australian Aboriginal Progressive Association, which drew inspiration from and mirrored many of the demands of these international black groups. A significant factor of the period, worldwide, was the move from rural environments to the cities by many black people seeking better working opportunities. ${ }^{51}$ This would be reflected in the nucleus of the 1920s Aboriginal movement - men like Fred Maynard,

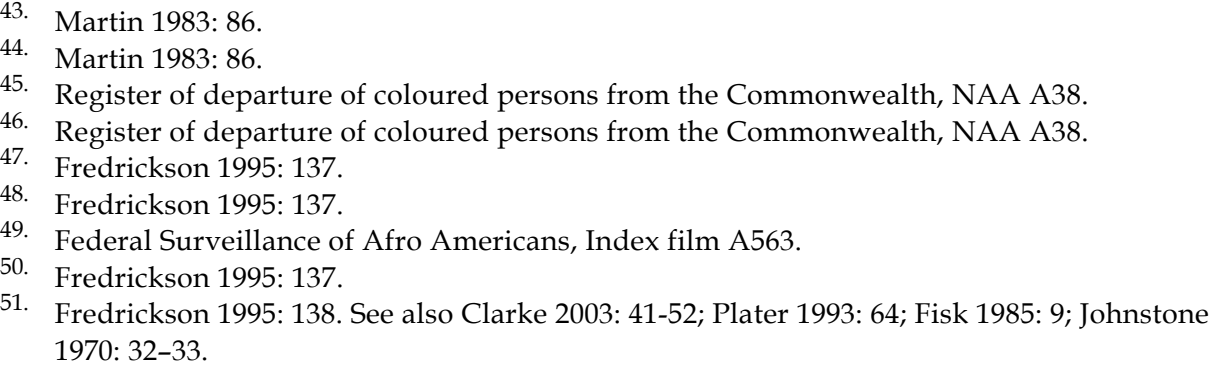


Tom Lacey, Dick Johnson and Sid Ridgeway - who were all working and living in Sydney and not confined on incapacitating reserves. The international black political surge reflected a strong push for equal, political, economic and social rights. But significantly for the rise of Aboriginal political protest, 'focussing on them to the exclusion of cultural issues could not satisfy the need of a people who had been humiliated by white supremacy for sources of group pride and a positive sense of identity' ${ }^{52}$

Through their contacts with African American seamen on the docks and waterfront of Sydney it is likely that the Aboriginal leaders of the 1920s including Fred Maynard had acquired knowledge of the works of Frederick Douglas, Booker T Washington, WEB Du Bois and Marcus Garvey, amongst others. Therefore international black movements and ideologies would form the core of the political directives and rhetoric of the 1920s Aboriginal leadership. A number of sources illustrate that these international black writers, and many more, were both available and sought after in Australia. A letter sent to Carter G Woodson, editor of the Journal of Negro History (and regarded by many as the 'Father of Negro History' ${ }^{53}$ ) demonstrates that point. The letter hints at a maritime connection: A Goldsmith, who described himself as a 'Negro Exile' sent his correspondence to Woodson from Port Melbourne in 1920. Goldsmith informed Woodson that the 'Negro papers I read out here [are] The Crisis, the Brownies Book, "Crusader", "Journal of Negro History", "The Negro World", the "Emancipator'". 54 Seeking Woodson's intellectual appraisal Goldsmith wrote: 'what do you think of them'. He enclosed 9/-6d to Woodson for his subscription for the journal Negro History. ${ }^{55}$ AAPA treasurer Tom Lacey's letter to Amy Jaques Garvey in 1924 substantiates the Australian interest in international black literature and newspapers. Lacey hinted at their propaganda potential: 'I would be very grateful to you if you could advise me how to get some of your American papers, The Negro World and other papers, so that I could distribute them among our people as it might help to enlighten them a bit'. ${ }^{56}$

It is important to consider not just the impact of newspapers like the Negro World but the attempts by white authorities to stamp out their circulation. 'The Negro World penetrated every area where black folk lived and had regular readers as far away as Australia' says historian Tony Martin:

It was cited by colonial powers as a factor in uprisings and unrest in such diverse places as Dahomey, British Honduras, Kenya, Trinidad and Cuba. These powers therefore had no illusions concerning the appeal of its message of racial self-reliance and its anticolonialist tone to oppressed black people. During its entire existence, therefore, the paper was engaged in a running battle with the British, French, United States and other governments, all of which assiduously sought to engineer its demise, or, failing that, to restrict or prevent its circulation. ${ }^{57}$

The rapid rise of Marcus Garvey had begun soon after his arrival in the United States from Jamaica in 1916. In less than a year, he had established the Universal Negro

\footnotetext{
Fredrickson 1995: 143.

Low \& Clift 1988: 868

Carter G Woodson Files, Reel 1 series 2 correspondence 1912-1950.

Carter G Woodson Files, Reel 1 series 2 correspondence 1912-1950.

56. The Negro World, 2 August 1924.

57. Martin 1976: 93.
} 
Improvement Association (UNIA) in New York. ${ }^{58}$ Greater racial consciousness in the aftermath of World War I was instrumental in attracting thousands of African American supporters, especially in Harlem. ${ }^{59}$

In January 1918, he [Garvey] launched the Negro World, a newspaper that Claude McKay, another Jamaican dubbed 'the best edited coloured weekly in New York'. In 1919 an attack on his life led to further publicity for Garvey as a persecuted martyr. ${ }^{60}$

Garvey's organisation experienced phenomenal growth and spread rapidly across the globe. The UNIA would stir 'the entire world of Negroes to a consciousness of race pride, which never existed before'. The organisation attempted to break 'down the barriers of racial nationality among Negroes and caused American, African, West Indian, Canadian, Australian [Aborigines] and South and Central American Negroes to realise they have a common interest' ${ }^{61}$ Garvey insisted the UNIA did not exclude anyone:

'For once we will agree with the American white man, that one drop of Negro blood makes a man a Negro.' In the UNIA '100 per cent Negroes and even 1 per cent Negroes will stand together as one mighty whole' ${ }^{62}$

Garvey and his platform 'struck a responsive chord in the hearts and minds of black people from an astonishing variety of social and cultural backgrounds throughout the world'. ${ }^{63}$ Adding further weight to the wharf connection is the fact that Garvey was able to achieve a worldwide network of information by sending out agents to spread his message, and many 'of those who did this work for him were seamen'. ${ }^{64}$

\section{The Australian branch of the Universal Negro Improvement Association}

At the height of its power in the mid-1920s, the UNIA had successfully established chapters in 41 countries, including a branch in Australia:

The Sydney, Australia UNIA branch was undoubtedly the furthest from Harlem. It illustrated how, in those days before even the widespread use of radio, Garvey and the UNIA were nevertheless able to draw communities from practically all over the world together into a single organization with a single aim. ${ }^{65}$

In August 1920, the UNIA held the first of a number of highly successful international conventions. Over 25,000 members gathered at Madison Square Garden in New York to hear Garvey speak. Members from UNIA branches across the globe 'attended from places as far apart as Australia, Africa and North America' ${ }^{66}$ Who were the Australian delegates present at that convention?

The Negro World reveals some information on the background and activities of the Sydney UNIA branch. A letter sent by the Sydney secretary Robert Usher and published in 1923 indicates the excitement and enthusiasm of the Australian group at a

\footnotetext{
Garvey 1970: 201.

Garvey 1970: 201.

60. Garvey 1970: 201.

1. Hill 1987: 327.

2. Levine 1993: 132.

3. Fredrickson 1995: 152.

64. Martin 1983: 86.

65. Martin 1983: 99.

66. Martin 1976: 42.
} 
time that the impact of Garvey and his organisation was 'resounding throughout the length and breadth of this small continent' ${ }^{67}$ Despite some difficulties the branch was now up and running and money was being spent in ensuring its growth. Usher revealed that many Aboriginal people in Australia were suffering low self-esteem and confidence 'but there are some of us who are doing our best to not only keep ourselves out of the mire, but to pull our brothers out as well'. The Sydney branch was adamant that they intended to push information of Garveyism to break ignorance within Aboriginal communities and provide inspiration: 'we are doing our best to bring them in line $^{\prime}{ }^{68}$ Usher was aware of Garvey's proposed world tour and expressed the hope he might include an Australian visit because 'we would like him to visit the Sydney Division'. ${ }^{69}$ A United States Federal surveillance report reveals that in 1923 Garvey had taken steps to undertake a world tour which included a month in Australia. The 'various branches of the UNIA are being requested to immediately arrange for Garvey's appearance before the branches' ${ }^{70}$

The letter from future AAPA treasurer Tom Lacey to Amy Jaques Garvey in 1924 reveals greater detail of the makeup and operation of the Sydney branch:

Dear Madam; I do hope you will excuse me for taking the liberty of writing to you, but I am doing so in the interests of our people. ${ }^{71}$

Lacey's letter pledged the future support of 10,000 Aboriginal people in NSW and 60,000 Aboriginal people nationally to Garvey and his movement. ${ }^{72}$ He stressed to Garvey, 'we have a great deal of work in front of us to do. What I mean by that is the native aboriginals of this state, New South Wales'. ${ }^{73}$ National expansion clearly lay at the forefront of the agenda. 'We have not had the time to organize the other four states yet, but I think there are about fifty or sixty thousand; that is as far as we can reach at the present time'. ${ }^{74}$ Lacey points out that he himself had been a member of the Sydney UNIA branch since 1920 and had recently been elected as the organiser of the Sydney chapter:

I myself take a great interest in the work. Nearly all my time is taken up with it. I started in 1920, that is four years ago, and they made me organizer this year, 1924. I hope before long you will be able to send us a delegate down here to Australia, as it would mean a great help to us. ${ }^{75}$

Despite his optimistic tone, this letter clearly revealed that the Aboriginal political fight would be hampered by the tight control exerted over many Aboriginal people confined on reserves by both missionaries and government Protection Boards:

We have a bit of trouble to see some of our people, as the missionaries have got the most of them, and we have great difficulty in reaching them. The authorities

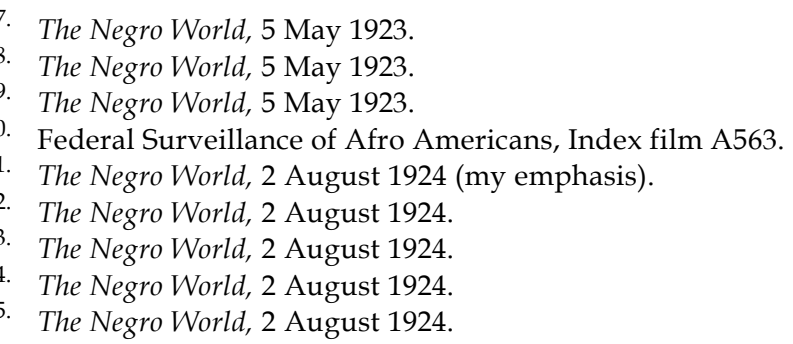


won't allow us to see them unless we can give them [the Aboriginal Board] a clear explanation of what we want them for. ${ }^{76}$

Lacey recognised the negative long-term effect of confinement on missions and reserves for the Aboriginal population. The authorities 'have got their minds so much doped that they think they can never become a people'. Lacey and others recognised Garvey as a great leader and a source of hope:

[Garvey] has done wonderful work since he started, and we will still continue to pray for him, that he may have great success in his great work. ${ }^{77}$

Lacey revealed that his sister was also involved with the Sydney UNIA branch and offered some evidence that Aboriginal people had taken up the initiative to inform the international black community of their plight in Australia:

My sister Mrs Hassen, is treasurer of this branch. She is also going to write to you, and send some Australian papers. ${ }^{78}$

Only months after this correspondence, news of the establishment of the AAPA was announced in Sydney and significantly there is no further recognition of a Sydney UNIA branch from this time on. The Aboriginal leaders had likely realised that an organisation of their own would be of much greater advantage. Nevertheless they saw parallels between the ideology of Garvey's movement and their own experiences. They cleverly unpacked Garvey's ideals and remodelled it to their own experience in Australia. They built their platform around Garvey's call for pride in culture, solid economic base, and strong association to land of birth.

\section{Media coverage: the black/white difference of opinion}

The Negro World during the 1920s provided a well informed coverage of the Aboriginal situation in Australia to its international black readership. Numerous articles appeared, for example, highlighting the movement to establish a 'Model Aboriginal Black State' in northern Australia, ${ }^{79}$ commentary on the restrictive 'White Australia' policy, ${ }^{80}$ and the use of violence directed against the Aboriginal population. Headline banners delivered vivid imagery of the Australian Aboriginal experience: 'Race Horrors in Australia Unspeakably Vile' ${ }^{81}$ and 'Killing off the Black Australians' ${ }^{82}$ The latter article explained to its uninformed readers that a great number of Aboriginal people were caged on government reserves 'and were being rapidly aided by so-called civilised man to join the extinct types'. ${ }^{83}$ This was compared with the Native American experience:

It is hardly believable that the white rulers of Australia, who have taken the country by force from the blacks, as they took the North American continent from the Red Men, have dealt with the black natives in a spirit of exterminating them root and branch, and with no regard whatsoever for the humanities. ${ }^{84}$

\footnotetext{
The Negro World, 2 August 1924.

The Negro World, 2 August 1924

The Negro World, 2 August 1924.

The Negro World, 17 October 1925.

The Negro World, 29 April 1922.

1. The Negro World, 27 September 1924.

2. The Negro World, 26 September 1925.

83. The Negro World, 26 September 1925.
} 
A report in the Negro World summarising the influence and impact of Garveyism around the globe in 1924, was titled 'Blacks of Australia enslaved and brutalised':

Everywhere the black man is beginning to do his own thinking, to demand more participation in his own government, more economic justice, and better living conditions. The Universal Negro Improvement Association during the past five years has blazed the trail for him, and he is following the trail. We do not think he will turn back. He has nothing to lose and everything to gain by pushing forward, whatever the obstacles he may encounter. ${ }^{85}$

In contrast, there was widespread media condemnation of Garvey and his movement in the Australian press during these years. Many of the articles were both racist and alarmist in their content:

Little is known in Europe of the movement of revolt and protest, which the New York International Congress of the negro-peoples of the world represents, but it is not to be ignored. It is a part of the menace to the domination of the white races, and it is vitally connected with the ever increasing power of Japan and the movement among the Moslems. The New York Congress began with a procession of negroes, many of them in elaborate uniforms, and among the banners was one depicting a black Virgin Mary leaning over a black child. This banner was a crude summary of the movement. The white man's domination is no longer accepted as inevitable, his predominance is frankly challenged. ${ }^{86}$

One writer in the Bellinger and Nambucca Times in 1925 exemplifies the levels of racist hysteria present at the time. The writer warned that the white race was in decline and decay 'not in culture or intellect, but numerically; the black race is growing swiftly, relentlessly, ruthlessly for all the rest of us, but for the whites especially. In 100 years from now the blacks may be supreme' ${ }^{87}$ The correspondent went on to remind the readers that in the United States and Canada:

the problem of the negro is always at their doors. They know all about Marcus Garvey. Memory is short, and it is perhaps worth while to recall who Mr Garvey is, and for what he stands ... there was a tendency to underestimate the real strength of the menace represented by the Universal Negro Improvement Association and African Communities League. ${ }^{88}$

He pointed out that the UNIA had established factories and an all-black steamship line. The article was an attempt to inflame the passion of the ignorant. In some quarters Garvey was credited as being some sort of new 'Moses'. The writer intimated that although Garvey and his organisation were forced into collapse through the actions of the authorities, this was in all likelihood only a temporary setback. The writer revealed his own insecurity by pointing out the precarious situation and threat to the white populace of the planet:

The hard fact remains, however, that in a relatively short campaign the League had from a nucleus of some fifteen stalwarts to a membership of somewhere in the

\footnotetext{
The Negro World, 26 September 1925.

The Negro World, 20 September 1924.

The Daylight, 30 October 1924: 797.

The Bellinger and Nambucca Times, 27 February 1925.

The Bellinger and Nambucca Times, 27 February 1925.
} 
neighbourhood of 2,000,000 organised in hundreds of branches; that it won a good deal of plausible sympathy; that many short sighted Americans even saw in the negro prophet's dream of a "Back to Africa" campaign a possible solution of the immediate problems in their own continent; and that there are some 400,000,000 negroes in the world population already with a power of prolific expansion shown by no other race. ${ }^{89}$

Another report in Adelaide's Advertiser confirms the fears and ignorance portrayed to the wider community of Marcus Garvey and his organisation. Garvey was described as a man who:

looks to the time when the yellow and white races will be locked in a great race war, the negroes will march over their weakened and prostrate bodies and enter into their own. The bloodiest of all wars is yet to come when Europe will match its strength against Asia and that will be the negroes opportunity to draw the sword for Africa. ${ }^{90}$

One can only guess at the alarm that would have been raised if it had been more widely known that a UNIA branch had operated in Sydney during the early 1920s. But there was no mention of this group in the Australian newspapers or government correspondence of the time.

Coinciding with the rise of black and Indigenous political voices during the time was the mobilisation of a growing number of international white philanthropic humanitarian and Christian reformists. Largely these people and groups operated under misguided assumptions that their perceived place of privilege allowed them to make decisions on behalf of disadvantaged groups. The significance of these white humanitarians and those imbued with religious zeal cannot be played down or devalued. However, the need for recognition of international black influences upon Aboriginal political activity is clearly evidenced by the present day Australian historical misconception that the AAPA was either driven by, or at least included, white Christian or nationalistic members. ${ }^{91}$

\section{The Australian Aboriginal Progressive Association}

The Australian Aboriginal Progressive Association (AAPA) burst into Australian public awareness in 1925 with front-page media coverage of their first conference staged in Sydney. ${ }^{92}$ During the next four years they fought a bitter campaign against the NSW Aborigines Protection Board. The AAPA held four conferences and established 11 branches with an active membership of over $500 .{ }^{93}$ When one considers that the entire Aboriginal population in New South Wales at the time was recorded as numbering less than 7000, with the great majority on restricted Aboriginal reserves with denied mobility, this was an incredible achievement. ${ }^{94}$ The AAPA platform centred on Aboriginal rights to their own land, citizenship, stopping the government practice of removing

89. The Bellinger and Nambucca Times, 27 February 1925.

90. The Advertiser, 18 April 1925.

91. McGregor 1997: 115; Attwood \& Marcus 1999: 59; Goodall 1996: 152. See also Attwood 2003.

92. The Daily Guardian, 7 May 1925.

93. Maynard 2005: 18. This is a remarkable number, considering that the government census of the entire Aboriginal population of New South Wales was under 7,000. 
Aboriginal children from their parents, and defending a distinct Aboriginal cultural identity. ${ }^{95}$

There has been academic misinterpretation and confusion in attempts to decipher the meaning of the AAPA logo, motto and the rhetoric of the Aboriginal leaders. ${ }^{96}$ The most prominent theories are that these arose out of Christian influence or white nationalism. Some have questioned these assumptions. Attwood and Marcus concluded that:

The AAPA's symbol had a motto 'One God, One Aim, One Destiny', but Maynard was influenced less by Christianity - although he had been raised in the church - than by his experiences as a young man as a drover and stockman throughout Australia and later as a wharfie and an active member of the Waterside Workers Union, by those of his family who had lost land when it was leased to white farmers. $^{97}$

Heather Goodall pointed out that Christian and white nationalist objectives were not reflected in the Association's agenda:

The emblem was an image of an Aboriginal man circled by the words 'Australia for Australians'. The AAPA frequently used the word 'Australian' rather than 'Aborigine'. The emblem was a thinly veiled reference to an indigenous people's assertion of nationhood. ${ }^{98}$

Although there have been questions raised, disputing preconceived assumptions relating to the AAPA motto and logo, no one has been able to unravel completely the mystery of its origin or its meaning. The fact is that the logo, motto and much of the political rhetoric of the AAPA were incorporated from the doctrine of Marcus Garvey and his group, the Universal Negro Improvement Association.

The clarion call of Garvey's Universal Negro Improvement Association was 'One God! One Aim! One Destiny!' 99 - the same as that of the later AAPA. In his poem 'Africa for the Africans', Garvey cried:

Europe Cries to Europeans, Ho!

Asiatics claim Asia, so

Australia for Australians

And Africa for Africans. 100

'Australia for Australians' was the battle cry featured on the AAPA logo. This was surely no coincidence. Garvey again included Australia in a long poem which sets out the world-wide impact of 'The tragedy of white injustice'. ${ }^{101}$ Garvey had originally titled this poem 'The white man's game, his Vanity Fair'. In it, Garvey ingeniously

94. The Sydney Morning Herald, 11 February 1925. (The following year, Board figures published in the Newcastle Morning Herald, 10 February 1926 saw the Aboriginal population rise to 7,072 in contradiction of the theory at the time of a rapidly 'dying race').

95. Maynard 2002: 33-36. See also Goodall 1988a: 186, 1988b: 6, 1990: 5; Creamer 1990: 151; Morris 1989: 171.

96. McGregor 1997: 115. See also Attwood \& Marcus 1999: 59.

97. Attwood \& Marcus 1999: 58.

98. Goodall 1996: 152.

99. Levine 1993: 112.

100. http://africawithin.com/garvey/garvey_poetry.htm accessed 25/07/05.

101. http://africawithin.com/garvey/garvey_poetry.htm accessed 25/07/05. 
incorporated, and saw parallels with, the suffering experienced at the infamous market place Vanity Fair, richly described in John Bunyan's Pilgrim's Progress:

Garvey employed the name of the town in his 1927 poem to encapsulate its theme of white oppression and decadence. Just as Bunyan's work is a kind of sacred picaresque in which evil is pitted against good, so Garvey's poem is a chronicle of the atrocities committed against native peoples by white colonizers. ${ }^{102}$

Garvey dissected and reworked Bunyan's plot to reflect the international experience of millions of Africans, Native Americans and Aboriginal Australians in the face of savage European colonial conquest. ${ }^{103}$ In their four years in the public spotlight, the Australian Aboriginal Progressive Association made continued demands through the media. There were frequent statements by Fred Maynard that the AAPA encouraged Aboriginal self-respect through spiritual, political, industrial and social ideals. Marcus Garvey had written in his manifesto 'We are organised for the absolute purpose of bettering our condition, industrially, commercially, socially, religiously and politically. ${ }^{104}$

Marcus Garvey and the Universal Negro Improvement Association had led a call for a symbolic and spiritual return to Africa and highlighted the importance of promoting a strong cultural identity. The call for a return to Africa meant nothing in Australia to the Aboriginal people, but the call for recognising cultural significance and the importance of their own homeland, struck a chord with the Aboriginal leaders. Fred Maynard's continued use of the term 'Australian people' instead of the more commonly used, 'Aboriginal' is thought-provoking. Some may well declare the name 'Australian' is just taking up another European tag. But Maynard may well have been insisting on Aboriginal association with the land and continent. The AAPA platform was all about defending traditional Aboriginal land tenure and cultural identity. Fred Maynard later declared: 'The Australian people are the original owners of the land and have a prior right over all other people in this respect' 105

Maynard and Lacey had closely studied and analysed the writing of Marcus Garvey. They had then shaped and remodelled this material to their own immediate needs. The Aboriginal leaders of the AAPA were eloquent, articulate statesmen far ahead of their time. They were very aware of international events and were able to utilise that knowledge to their advantage. AAPA Treasurer Tom Lacey was described as:

not only a fluent speaker but a veritable Lincoln of phraseology. He is possibly the best-informed man in the State regarding the movement for the emancipation of the slaves in America and Cuba, and he is bringing all his native intelligence to bear on the subject. ${ }^{106}$

Lacey had set himself the task of informing his people of their denied place in white society. Despite that, his message was overwhelmingly positive regarding their

\footnotetext{
102. Hill 1987: xxxii.

103. Hill 1987: xxxii.

104. Garvey 1970: 55.

105. Maynard, F 1927, NSW Premiers Department Correspondence Files A27/915.

106. The Voice of the North, 10 October 1927.
} 
prospects. If empowered they were capable of achieving and overcoming all manner of obstacles:

From end to end of N.S.W. the name of Lacey is known and admired. He is a keen debater and will be hailed as a modern Moses. The slogan 'No more slavery in N.S.W.' will reverberate throughout the length and breadth of the continent, and will not only have the effect of breaking the chains off the aboriginals in the prison gangs of West Australia, but will straighten out every grievance which the native people are enduring under the respective Australian Governments in general but those of New South Wales particularly. ${ }^{107}$

In another appraisal, Tom Lacey was described 'as an impressive speaker [who] claims that the Aboriginals of Australia can attain to the same position as the coloured people of the United States, who have their own colleges and universities. He resents the actions of our parliamentarians whose laws place the Aboriginals in the category of children or imbeciles. ${ }^{108}$

Fred Maynard was described as an 'orator of outstanding ability, and in the not far distant future will loom large in the politics of this country for the reason that the aboriginal question is becoming a very important one' ${ }^{109}$ Self-educated on a wide variety of topics, and a voracious reader who continued to educate himself, ${ }^{110}$ Maynard's awareness of international - particularly black - issues and events is clearly articulated in his correspondence attacking the New South Wales Aborigines Protection Board. 'What a horrible conception of so-called legislation, re any civilized laws, I say deliberately stinks of the Belgian Congo', he wrote of the Board's repressive legislation. ${ }^{111}$ His earlier association with the Coloured Progressive Association, and his other links to African American men and women linked to the Universal Negro Improvement Association led the New South Wales Aborigines Protection Board to attempt to discredit and defame Maynard's Aboriginal background and character. In correspondence from the Board to Premier Jack Lang, the inference made was quite explicit: he could not possibly be Aboriginal and his representations 'should not be allowed to unduly occupy the Premier's time. Mr Maynard is a full blooded black (either American or South African) whose voluble manner and illogical views are more likely to disturb the Australian Aborigines than achieve for them improvement of conditions.' $^{112}$

Knowledge of Marcus Garvey and his Universal Negro Improvement Association, despite success and widespread recognition, was rapidly lost. The material presented here provides evidence that the early Aboriginal political agenda was very much influenced by Marcus Garvey and the UNIA. The Australian Aboriginal Progressive Association had formulated its political platform based on decades of experience and

107. The Voice of the North, 10 October 1927.

108. The Voice of the North, 11 January 1926.

109. The Voice of the North, 11 January 1926.

110. Maynard-Kondek 1988: 175.

111. Maynard, F 1927, Letter to Aboriginal girl, NSW Premiers Department Correspondence Files A27/915.

112. NSW Premiers Department Correspondence Files 9/11/1927, A27/915. 
knowledge of international black issues. The belief that 'whites knew best' and were 'pulling the strings' of early Aboriginal political activity continues to contaminate present-day analyses. For example, Attwood says 'the influence of white activists, especially on the political discourses that shaped debate about rights for Aborigines, was much greater than any other influence' ${ }^{113}$ This is not meant to demean or deny the role played by white supporters in early Aboriginal political mobilisation (who did play a prominent part) but is intended to present a more balanced understanding.

The discourse that influenced the AAPA in the 1920s was black internationalism. The Aboriginal activists of the period were well informed, independent and far-sighted with their political goals. Despite the evidence and documentation to support the significant impact the AAPA made, it was erased from the Australian historical landscape in a very short space of time. As a result, Aboriginal Australians in later decades were severed from this inspirational knowledge of their history. Sadly, this process has denied Aboriginal and African American activists their deserved place of prominence in Australian historiographical memory.

\section{Acknowledgements}

A different version of this article is to be published as a chapter "In the interest of our people': the rise of Aboriginal political activism and Garveyism', in T Martin (ed) Global Garveyism, Majority Press, USA.

\section{References}

\section{Unpublished sources}

Federal Surveillance of Afro Americans 1917-1925, 'The First World War, Red Scare and the Garvey Movement', Lamont Library, Harvard University. Index film A563

Goodall, H 1998, 'Evans Head History Report' application for a native title determination number NG 6034

Carter G Woodson Files, Library of Congress, Washington DC, Reel 1 series 2 correspondence 1912-1950

Maynard family photograph, courtesy Cheryl Oakenfall

National Archives of Australia, D596, Memo no 5934/08, 'Relative to the issue of Certificate of Exemption in favour of Jack Johnson'

National Archives of Australia A38, 'Register of departure of coloured persons from the Commonwealth'

NSW Premiers Department Correspondence Files A27/915

NSW Premiers Department Correspondence Files 9/11/1927, A27/915

\section{Newspapers}

The Negro World

Daylight

The Referee

The Truth

113. Attwood 2003: xiii. 
The Daily Express (London)

The Bellinger and Nambucca Times

The Advertiser (Adelaide)

The Sydney Morning Herald

Newcastle Morning Herald

The Voice of the North

The Crisis (Schomberg Center for Research in Black Culture, New York Public Library, Harlem, New York)

\section{Secondary sources}

Attwood, B 2003, Rights for Aborigines, Allen and Unwin, Sydney.

— and Marcus, A 1999, The struggle for Aboriginal rights, Allen and Unwin, Sydney.

Broome, R 2001, Aboriginal Australians, Allen and Unwin, Sydney.

Butlin, N 1983, Our original aggression, Allen and Unwin, Sydney.

Chesterman, J and Galligan, B 1997, Citizens without rights, Cambridge University Press, Australia.

Clarke, B 2003, Wisdom man, Viking, Australia.

Commonwealth Government, Human Rights Equal Opportunity Commission 1997, Bringing Them Home Report: A Report of the National Inquiry into the Separation of Aboriginal and Torres Strait Islander Children from their Families, Sydney.

Corris, P 1980, Lords of the ring: a history of prize fighting in Australia, Cassell, Australia.

Creamer, H 1990, 'Malaise and beyond', in Stanbury, P (ed), The moving frontier, A.H \& A.W Reed Pty Ltd, Sydney.

Davis, D 2001, In the image of God, Yale University Press, United States.

Dawson, M 2001, Black visions, The University of Chicago Press, Chicago.

Fisk, R 1985, The Aboriginal economy in town and country, Allen \& Unwin, Sydney.

Fleischer, $\mathrm{N}$ nd, The ring: boxing the 20th century, The Ring, United States.

Fredrickson, G 1995, Black liberation: a comparative history of Black ideologies in the United States and South Africa, Oxford University Press, New York.

Fryer, P 1984, Staying power: the history of Black people in Britain, Pluto Press, London.

Garvey, M 1970, 'Philosophy and opinions', in George Ducas and Charles van Doren (eds), Great documents in Black American history, Proeger Publishers, New York.

Goodall, H 1988a, 'Cryin out for land rights', in Burgman, V \& Lee, J Staining the Wattle, McPhee Gribble Publishers, Victoria.

_ 1988b, 'Aboriginal calls for justice: learning from history, Aboriginal Law Bulletin, 2(3): $4-5$

-1990, 'Land in our own country', Aboriginal History, 14: 1-24.

— 1996, Invasion to embassy, Allen and Unwin, Sydney.

Grimshaw, P, M Lake, A McGrath and M Quartly 1994, Creating a nation 1788-1990, McPhee Gribble Publishers, Victoria.

Haebich, A 2000, Broken circles, Fremantle Arts Centre Press, Fremantle.

Hill, R (ed) 1987, Marcus Garvey: life and lessons, University of California, California. 
Johnstone, S 1970, 'The New South Wales Government policy towards Aborigines 1880 to $1909^{\prime}$, MA thesis, University of Sydney.

Levine, L 1993, The unpredictable past: explorations in American cultural history, Oxford University Press, New York.

Linebaugh, P \& Rediken, M 2000, The many headed hydra: sailors, slaves, commoners, and the hidden history of the revolutionary Atlantic, Beacon Press, Boston.

Low, W and A Clift (eds) 1988, Encyclopedia of Black America, De Capo Press, New York. Malcolm X 2001, The final speeches, Pathfinder, New York.

Martin, T 1976, Race first, Majority Press, Massachusetts.

— 1983, Marcus Garvey, hero, Majority Press, Massachusetts.

Maynard, J 1997, 'Fred Maynard and the Australian Aboriginal Progressive Association (AAPA): one god, one aim, one destiny,' Aboriginal History 21: 1-13.

- 2002, 'Defense of the sacred "ancient code"', Cultural Survival Quarterly 26(2): 33-36.

— 2003a, 'Vision, voice and influence: the rise of the Australian Aboriginal Progressive Association', Australian Historical Studies 34(121): 91-105.

-2003b, 'Fred Maynard and the awakening of Aboriginal political consciousness in twentieth century Australia', PhD thesis, University of Newcastle.

2005 'Light in the darkness', in Paisley, F, Haskins, V and Cole, A (eds) Uncommon ground: white women in Aboriginal history, Aboriginal Studies Press, Canberra: 3-27.

Maynard-Kondek, M 1988, 'Charles Frederick Maynard: vision for justice for Aborigines', in Baldwin, S (ed) Unsung heroes and heroines, Greenhouse Publications, Victoria (article edited by Billy Marshall-Stoneking).

McGregor, R 1997, Imagined destinies: Aboriginal Australians and the doomed race theory 1880-1939, University of Melbourne Press, Melbourne.

Morris, B 1989, Domesticating resistance: the Dhan Gadi Aborigines and the Australian State, St Martins Press, Sydney.

Murphy, B 1982, Dictionary of Australian history, Fontana/Collins, Melbourne.

Peterson, N and Saunders, W 1998, Citizenship and Indigenous Australians: changing conceptions and possibilities, Cambridge University Press, Melbourne.

Plater, D 1993, Other boundaries: inner-city Aboriginal stories, Bagnall Publications, Leichhardt Municipal Council, Sydney.

Read, P 1999, A rape of the soul so profound, Allen and Unwin, Sydney

Wells, G 1998, Boxing Day: the fight that changed the world, Harper Collins, Sydney.

Willis, I 1994, 'Australian Aboriginal Progressive Association', in Horton, D (ed) The Encyclopaedia of Aboriginal Australia, Aboriginal Studies Press, Canberra: 75. 